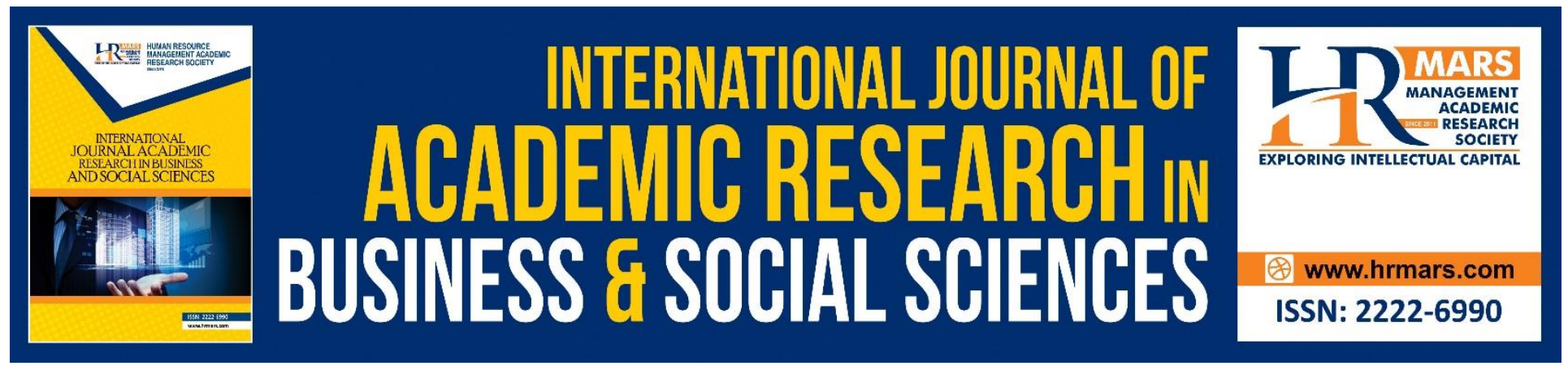

\title{
Using MOA Framework in Predicting Research Productivity of Faculty Members with Mediation Role of Knowledge Creation Process
}

Mery Citra Sondari

To Link this Article: http://dx.doi.org/10.6007/IJARBSS/v8-i10/5276

DOI: $10.6007 /$ IJARBSS/v8-i10/5276

Received: 14 Sept 2018, Revised: 19 Oct 2018, Accepted: 26 Oct 2018

Published Online: 03 Nov 2018

In-Text Citation: (Sondari, 2018)

To Cite this Article: Sondari, M. C. (2018). Using MOA Framework in Predicting Research Productivity of Faculty Members with Mediation Role of Knowledge Creation Process. International Journal of Academic Research in Business and Social Sciences, 8(10), 1171-1180.

Copyright: (C) 2018 The Author(s)

Published by Human Resource Management Academic Research Society (www.hrmars.com)

This article is published under the Creative Commons Attribution (CC BY 4.0) license. Anyone may reproduce, distribute, translate and create derivative works of this article (for both commercial and non-commercial purposes), subject to full attribution to the original publication and authors. The full terms of this license may be seen at: $\underline{\text { http://creativecommons.org/licences/by/4.0/legalcode }}$

Vol. 8, No. 10, 2018, Pg. 1171 - 1180

Full Terms \& Conditions of access and use can be found at http://hrmars.com/index.php/pages/detail/publication-ethics 


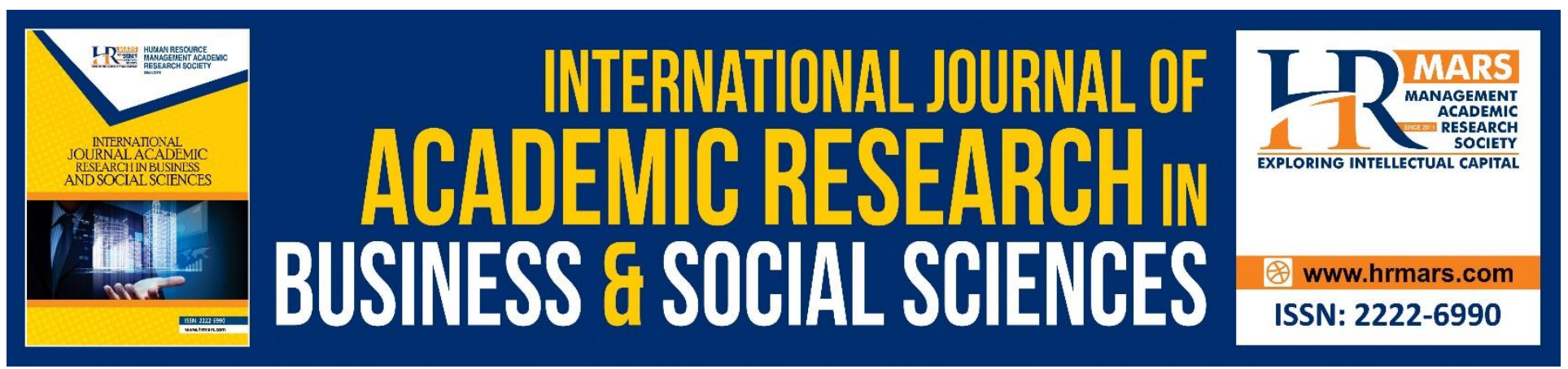

\title{
Using MOA Framework in Predicting Research Productivity of Faculty Members with Mediation Role of Knowledge Creation Process
}

\author{
Mery Citra Sondari \\ Faculty of Economics and Business, Universitas Padjadjaran, Indonesia \\ Email: mery.sondari@unpad.ac.id
}

\begin{abstract}
The world now is entering a knowledge-based era that emphasizes knowledge production through research, that is one of the main functions of higher education institutions (HEIs). This research aims to examine the antecedent factors of faculty member's research productivity and the role of knowledge creation process in the model of the antecedent factors of faculty member's research productivity. This research employed quantitative-survey design to collect data from 307 samples from $45 \mathrm{HEls}$ in Indonesia and 125 samples from $31 \mathrm{HEls}$ in Malaysia. Based on data analysis using smart-PLS 3, revealed that academia knowledge creation process significantly affect research productivity and have a role as a mediator in the influence of research motivation towards research productivity and the influence of research competency towards research productivity.
\end{abstract}

Keywords: Research productivity, Higher Education Institution, Faculty member, MOA framework, Knowledge Creation Process, Mixed-method, comparative study

\section{INTRODUCTION}

The world now is entering a knowledge-based era that emphasizes knowledge production through research, which is one of the main functions of higher education institutions (HEIs). HEls in Asia, especially those in south-east Asia lag behind HEls from western world in term of research productivity although Asia countries, in general, have experienced positive growth in research productivity for over the twenty-five-years period (Mouton \& Waast, 2009). It gave the impact that HEIs from South-east Asian region have an inferior position in the world university ranking compare to HEls from other regions. In the top universities world ranking released by QS, in 2016, there are only 11 universities from south-east Asia region that were included in the top 500 list. There are five universities from Malaysia; Two universities from each Singapore and Thailand, and one university from each Philippines and Indonesia. 
After all, because research productivity of higher education institution (HEI) is the sum of research conducted by its faculty member (Hesli \& Lee, 2011; Ju, 2010) thus, research productivity of HEI also reflects the performance of its faculty member (Hesli \& Lee, 2011; Kaufman, 2009). Therefore, institutions should endeavor to understand the factors that can influence research productivity of the individual faculty member. In organizational behavior studies, there is a well-established framework, that is called The Motivation-Opportunity-Ability (MOA) framework (Blumberg \& Pringle, 1982), to explain the antecedents of individual performance. This framework postulate that all three of these variables should be present for a behavior to occur (Fadel \& Durcikova, 2014). To represent the MOA - a framework in this research, specific variables were assigned, namely: research motivation, research competency, and perceived research opportunity. Research motivation is conceptualized as both intrinsic and extrinsic factors that drive faculty member to do research. Both extrinsic and intrinsic motivators empirically proven have a positive relationship with individual's performance (Aydin, 2012). An Ability is an individual's capacity to perform the various tasks in a job (Robbins \& Judge, 2009). However, because it is believed that to do research, faculty members should have specific characteristics of ability, so that in this research, the term 'competency' is used instead of ability. It is because competency can be defined as ability required for effective performance (Marrelli, Tondora, \& Hoge, 2005). Thus, research competency is conceptualized as faculty member's behavior that leads to superior research productivity. Competency is believed causal relation with performance (Spencer.Jr. \& Spencer, 1993). In MOA framework, an opportunity can be described as operational constrain (Tuuli, 2012). In this research, the focus is whether those factors are perceived available of the individual. Thus, opportunity factors in this research are called perceived research opportunity which is conceptualized as institutional resources and policies that perceived by faculty member available to facilitate him/her to do research. Those institutional resources and policies are believed the keys to the success of academic research in higher education institution (Zainab, 1999). After all, factors of motivations, opportunity, and ability in MOA framework are interrelated (Fadel \& Durcikova, 2014). Although how those variables interact each other are still unclear, some scholars found that institutional factors such as training system and rewards system are significantly influenced specific competency (knowledge generation competence) (Griese, Pick, \& Kleinaltenkamp, 2012). It is also found that financial rewards provided by organization or pressure from institutional policy significantly affect research performance (Chaiyasoonthorn, Jongtrakul, \& Sheehan, 2013). Thus, it can be hypothesized, that: (i) Research motivation significantly affect research productivity; (ii) Research competency significantly affect research productivity; (iii) Perceived research opportunity significantly affect research productivity; (iv) Perceived research opportunity significantly affect research motivation; (v) Perceived research opportunity significantly affect research competency.

Research productivity is believed as an outcome of knowledge creation process. Since this is an individual level research, the focus is to examine how an individual faculty member participates in knowledge creation as part of academia community. Academia defined as "a collective term for the scientific and cultural community engaged in higher education and research, taken as a whole while academic means someone who has a scholarly background" (Jusoff \& Samah, 2009). Therefore, in this research, the term used is academia knowledge creation process that is conceptualized as faculty 
member's participation in socialization, externalization, combination and internalization discourses in a specific place of context (ba). This construct adopted the SECI model developed by Nonaka and colleagues (Nonaka, Byosiere, \& Borucki, 1994; Nonaka, Krogh, \& Voelpel, 2006; Nonaka, Toyama, Hirata, \& Edwards, 2009; Nonaka \& Krogh, 2009; Nonaka \& Takeuchi, 1995; Nonaka \& Toyama, 2005). Ba that is simply translated as a 'place', actually can be a physical, virtual or mental places, where people or the idea interact in some conversion modes (tacit to tacit; tacit to explicit; explicit to explicit; explicit to tacit) to create knowledge (Tian, Nakamori, \& Wierzbicki, 2009). Travaille and Hendriks (2010) through their qualitative studies, has found a series of 'best practice' that are related to research productivity. Their respondents have been asked about a way or strategy that in their opinion related to their research performance. The study resulted in a series of SECl (SocializationExternalization-Combination-Internalization) activities that are considered significant as a predictor of a 'successful scientist' (Travaille \& Hendriks, 2010). Therefore, it can be hypothesized, that: (vi) Academia knowledge creation process significantly affect research productivity. Conceptually, the motivation-opportunity-ability factors have been implicitly brought up by Nonaka and Takeuchi (1995) when they talk about the enabling factors for knowledge creation: intention, autonomy, fluctuation and creative chaos, redundancy, and requisite variety (Nonaka \& Takeuchi, 1995). Travaille and Hendriks (2010) discuss the implementation of five enabler factors in the context of higher education. Factor intention defined as the individual's or organization's aspiration to its goals, that is according Travaille and Hendriks (2010), the mission of the higher education institution that links to the purpose, utility or relevance of science. It is needed to provide clear direction of research activities in higher education institution. Autonomy factor associated with the image of the scientist as a free and autonomous profession (Travaille \& Hendriks, 2010). It is related to job characteristic model of motivation. Fluctuation and creative chaos can be related to the nature of research environment that can be categorized as an opportunity. Redundancy, which is defined as the intentional overlap between experience and knowledge (Travaille \& Hendriks, 2010), can be associated with the human capital factors as well as requisite variety, refers to the mix of competencies that are needed to produce a particular output of research (Travaille \& Hendriks, 2010). Thus, motivation, ability, and opportunity factor in MOA framework may influence knowledge creation process, since those factors are what Nonaka and Takeuchi said as knowledge creation enabler (Nonaka \& Takeuchi, 1995). Therefore, it can be hypothesized, that: (vii) Research motivation significantly affect academia knowledge creation process; (viii) Research competency significantly affect academia knowledge creation process; (ix) Perceived research opportunity significantly affect academia knowledge creation process; and $(x)$ Academia knowledge creation process serve as a mediator in the influence of research motivation, research competency and perceived research opportunity towards research productivity. 


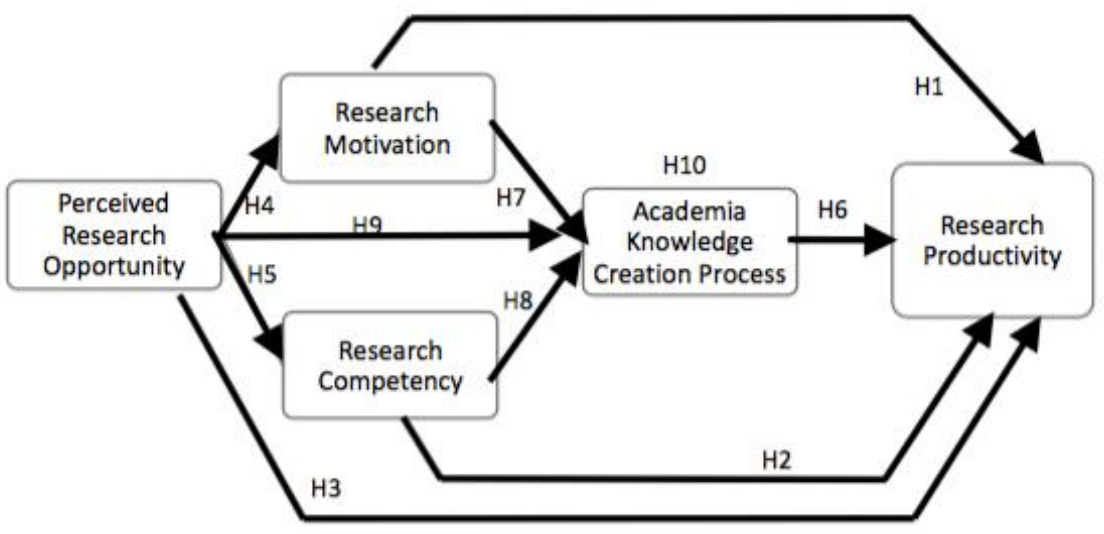

Fig.1: Research framework

\section{METHOD}

The survey method was used in this research to obtain data from the respondents, using self-report written questionnaires. Sampling technique used in this research is purposive sampling, which is a type of non-probability sampling in which the researcher's judgment is used to select the sample members based on a specific criterion (Saunders, Lewis, \& Thornhill, 2008). The criterion used for the judgment is that HEls that included in the sampling frame are those that are listed in the Scopus index. Started in January 2017, the questionnaires link and soft-file (in excel format) were sent through e-mail based on the e-mail address in the database. Every three days, the reminder e-mail was sent, in total up to three of reminders. Because of the low response rate, the reminder e-mails were sent again in the following month. Then, snowball sampling was conducted to increase the response rate. In the end, total 432 applicable questionnaires were managed, that came from $45 \mathrm{HEls}$ in Indonesia and $31 \mathrm{HEls}$ in Malaysia and consisted of 307 questionnaires from Indonesia, and 125 questionnaires from Malaysia

This research used partial least square (PLS) method to analyze the explanatory model. The bootstrap resampling method (with 500 resamples) was used for the analysis to determine the significance of the path coefficients. Because this model employed hierarchical component model, consequently, the path relationship between any additional latent variable as the predecessor and the endogenous HOC is always approximately zero and nonsignificant (Hair, Hult, Ringle, \& Sarstedt, 2014). In this situation, a two-stage approach should be used (Hair et al., 2014). In second-stage approach, the second processing is conducted using the latent variable score of the higher order construct.

\section{RESULTS}

The result of partial least square (PLS) method revealed that 'Academia Knowledge Creation Process' has significant effect towards research productivity $(0,223)$. All of three MOA-framework components, namely 'Research Motivation', 'Research Competency', and 'Perceived Research Opportunity' however do not affect research productivity significantly, but, the path from 'Research Motivation' $(0,237)$ and 'Research Competency' $(0,435)$ towards 'Academia Knowledge Creation Process' are significant, so that it is possible that 'Academia Knowledge Creation Process' serve as a 
INTERNATIONAL JOURNAL OF ACADEMIC RESEARCH IN BUSINESS AND SOCIAL SCIENCES

Vol. 8, No. 10, Oct. 2018, E-ISSN: 222 2-6990 @ 2018 HRMARS

mediator in the relationships between 'Research Motivation' and 'Research Competency' toward 'Research Productivity'. 'Perceived Research Opportunity as expected, has significant effect towards 'Research Motivation' $(0,216)$ and 'Research Competency' $(0,157)$. Those results are illustrated in figure 2.

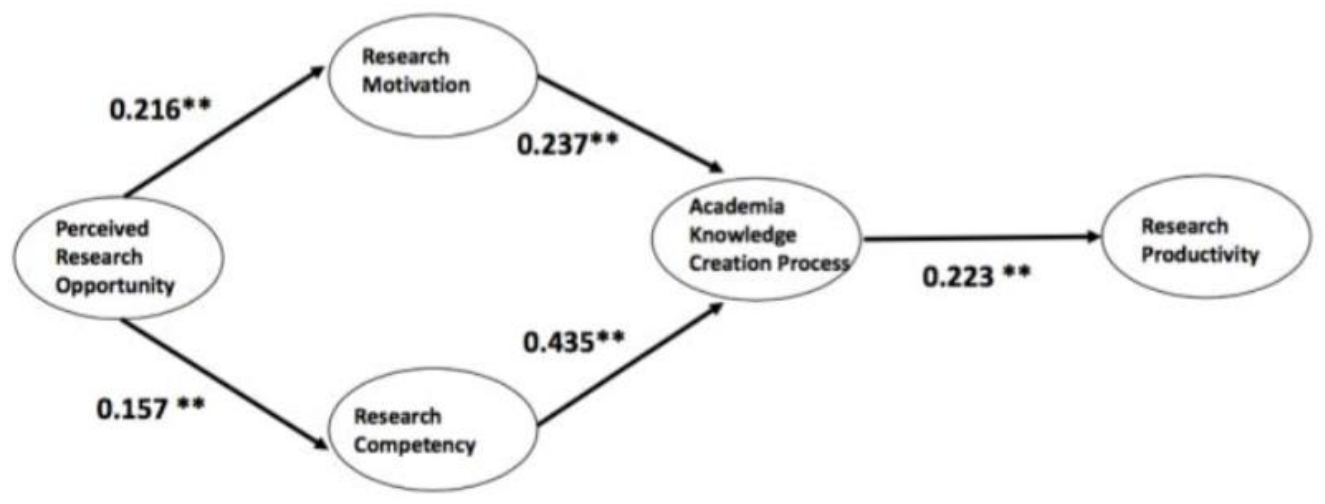

Fig.2: Result of smart-PLS 3 (structural model)

From the previous section, the result shows that the path from 'Research Motivation' $(0,237)$ and 'Research Competency' $(0,435)$ towards 'Academia Knowledge Creation Process' are significant and so the path from 'Academia Knowledge Creation Process' $(0,223)$ towards 'Research Productivity.' Therefore, it is possible that 'Academia Knowledge Creation Process' serve as a mediator in the relationships between 'Research Motivation' and 'Research Competency' toward 'Research Productivity.' To test the hypothesis, it is needed to examine whether the indirect effect towards the targeted variable that involves the mediator is significant or not. From table.1 can be seen that indirect effects toward research productivity from 'Research competency' and 'Research motivation' (via academia knowledge creation process) are significant, while the path from 'Perceived research opportunity' is not significant. Thus, it can be concluded that there is no mediation effect of 'Academia knowledge creation process' on the path between 'Perceived research opportunity', but there are significant mediation effects of 'Academia knowledge creation process' on the path between 'Research competency' and 'Research productivity' and the path between 'Research motivation' and 'Research productivity'. It is because the significant indirect effect is required to conclude that there is a mediation effect on the relationship represented by the indirect effect (Hair et al., 2014). 
INTERNATIONAL JOURNAL OF ACADEMIC RESEARCH IN BUSINESS AND SOCIAL SCIENCES

Vol. 8, No. 10, Oct. 2018, E-ISSN: 222 2-6990 @ 2018 HRMARS

Table 1. Mediation analysis

\begin{tabular}{|l|l|l|l|l|l|c|}
\hline & $\begin{array}{l}\text { Direct } \\
\text { Effect }\end{array}$ & $\begin{array}{l}\text { Indirect } \\
\text { Effect }\end{array}$ & $\begin{array}{l}\text { T } \\
\text { Statistics } \\
\text { of } \\
\text { Indirect } \\
\text { effect }\end{array}$ & $\begin{array}{l}\text { P Values } \\
\text { of indirect } \\
\text { effect }\end{array}$ & $\begin{array}{l}\text { Total } \\
\text { Effect }\end{array}$ & VAF \\
\hline $\begin{array}{l}\text { Research } \\
\text { Competency -> } \\
\text { Research Productivity }\end{array}$ & 0.063 & 0.098 & $4.833^{* *}$ & 0 & 0.151 & $65 \%$ \\
\hline $\begin{array}{l}\text { Research Motivation - } \\
\text { Pesearch } \\
\text { Productivity }\end{array}$ & -0.064 & 0.054 & $3.717^{* *}$ & 0 & -0.013 & $\begin{array}{c}\text { suppresso } \\
r\end{array}$ \\
\hline $\begin{array}{c}\text { Perceived Research } \\
\text { Opportunity -> } \\
\text { Research Productivity }\end{array}$ & -0.048 & 0.02 & 1.451 & 0.074 & & n.a \\
\hline
\end{tabular}

To find the size of mediation effect, the values of the variance accounted for (VAR) should be examined first. The VAF equals the direct effect divided by the total effect (Hair et al., 2014). As indicated in Table III.19, VAF for the mediation effect on the path between 'Research competency' and 'Research productivity' equals to $65 \%$ that is above $20 \%$ but still less than $80 \%$, which means that there is a partial mediation served by 'Academia knowledge creation process' on the path. VAF for the path between 'Research motivation' and 'Research productivity' is negative, which means that the mediation has a suppressor effect, characterizes the sign change of the direct relationship after the mediator variables have been included, and this situation always represents full mediation (Hair et al., 2014).

\section{DISCUSSION}

This research has no evidence that 'Research Motivation,' 'Perceived Research Opportunity' and 'Research Competency,' the components of a theoretical MOA-framework (Blumberg and Pringle, 1982) significantly affect 'Research Productivity.' However, 'Research Motivation,' and 'Research Competency' significantly affect 'Academia Knowledge Creation Process' respectively with coefficients equal to 0.237 and 0.435 , and 'Academia Knowledge Creation Process' significantly affect 'Research Productivity' with the coefficient equals to 0.233 . Thus, 'Academia knowledge creation process' serve as a mediator on the path between 'Research Motivation' and 'Research productivity' (Full mediation), and on the path between 'Research competency' and 'Research productivity' (partial mediation). In other words, 'Research motivation' and 'research competency' still have indirect effects toward research productivity, as long as they go through the academia knowledge creation process. It means that high research motivation of faculty members would not increase their productivity, without participating in academia knowledge process.

Explaining the un-significant influence of motivation towards research productivity, a study from Heywood et al. (2011) also can be considered. They found that extrinsic motivation in term of 
incentive can increase research productivity (Heywood, Wei, \& Ye, 2011), but it only works for the active researcher, those who involved in the whole process of research and the process of knowledge creation. So, the incentive can motivate, but cannot help those who have never involved in the knowledge creation process to increase their productivity. In the case of research competency, sometimes even the most competent researcher also needs to collaborate with another researcher to published some articles. The collaboration, one of the activities in the academia knowledge creation process, is proven to have significant effect towards publication (Miller, Coble, \& Lusk, 2013). It is also relevant to a study from Chandran, Hayter and Strong (2015), that found that consulting experience (in this research included in the internalization process), can increase the likelihood of publication up to 13 percent (Chandran, Hayter, \& Strong, 2015). This result is significant for organizational behavior studies since it put the knowledge-related variables to the higher level where in the past, the role of this variables is missed to be examined in explaining individual performance. This research has proven that knowledge-related variables, in this case, knowledge creation, play even the main role, at least in the context of academia.

'Research Motivation' is significantly influenced by 'Perceived Research Opportunity' with the coefficient equals to 0.216 and 'Perceived Research Opportunity' also significantly influences 'Research Competency' with 0.157 of the coefficient. The result shows that MOA-framework components are dynamic, where one component (perceived research opportunity) have significant influence toward two others. This result support Siemsen, Roth, Balasubramanian (2008) that suggest those components should not be addressed independently, but rather in a dynamic and coordinated way (Siemsen, Roth, \& Balasubramanian, 2008). From this model, we can see the role of perceived research opportunity as the root, that should exist first as a necessity, although it is not then found not a sufficient factor. So, it is not wrong-indeed it should be- to emphasize the fulfillment of facilities and infrastructure as long the expectation is not that those facilities and infrastructure will turn the input automatically to produce output. That is where the process, in this case, the process of knowledge creation is needed, as proven by this research.

\section{CONCLUSION}

Examining the antecedent factors of research productivity using smart-PLS 3, resulted that MOAframework components in this research, namely, Research motivation, Research competency and Perceived research opportunity do not have a significant influence towards research productivity. Research motivation and Research competency significantly affect Academia knowledge creation process, and perceived research opportunity was proved have significant effects toward research motivation and research competency. Academia knowledge creation process significantly affects research productivity and have a role as a mediator in the influence of research motivation towards research productivity and the influence of research competency towards research productivity.

Based on the result of this research, higher education institutions are recommended to enhance the activities related to the Academia knowledge creation process, by facilitating research group meeting, establishing joint collaboration research and inviting fellow researcher (socialization); facilitating faculty members to attend international conferences and providing facilities to held many dissemination forum (externalization); facilitating and supporting faculty members to write textbooks and facilitating faculty members to write decent research report (combination); increasing numbers 
INTERNATIONAL JOURNAL OF ACADEMIC RESEARCH IN BUSINESS AND SOCIAL SCIENCES

Vol. 8, No. 10, Oct. 2018, E-ISSN: 222 2-6990 @ 2018 HRMARS

of research project by giving facilities in form of sufficient research funds, encouraging and facilitating faculty members to manifest each stage of their research into an article to be published (internalization).

\section{REFERENCES}

Aydin, O. T. (2012). The Impact of Motivation and Hygiene Factors on Research Performance : An Empirical Study from A Turkish University. International Review of Management and Marketing, 2(2), 106-111.

Blumberg, M., \& Pringle, C. D. (1982). The Missing Opportunity in Organizational Research: Some Implications for a Theory of Work Performance. The Academy of Management Review, 7(4), 560-569.

Chaiyasoonthorn, W., Jongtrakul, J., \& Sheehan, B. (2013). Experience of Prominent Academic Researchers in Thai Public Universities. HRD Journal, 4(1), 86-99.

Chandran, V. G. R., Hayter, C. S., \& Strong, D. R. (2015). Personal strategic alliances: enhancing the scientific and technological contributions of university faculty in Malaysia. Economics of Innovation and New Technology, 24(5). http://doi.org/10.1080/10438599.2014.988501

Fadel, K. J., \& Durcikova, A. (2014). Enhancing the Motivation, Opportunity, and Ability of Knowledge Workers to Participate in Knowledge Exchange. In 2014 47th Hawaii International Conference on System Science Enhancing (pp. 3605-3614). http://doi.org/10.1109/HICSS.2014.449

Griese, I., Pick, D., \& Kleinaltenkamp, M. (2012). Antecedents of knowledge generation competence and its impact on innovativeness. http://doi.org/10.1108/08858621211251479

Hair, J. F. J., Hult, G. T. M., Ringle, C., \& Sarstedt, M. (2014). A Primer on Partial Least Squares Structural Equation Modeling (PLS-SEM). Long Range Planning (Vol. 46). http://doi.org/10.1016/j.Irp.2013.01.002

Hesli, V. L., \& Lee, J. M. (2011). Faculty Research Productivity: Why Do Some of Our Colleagues Publish More than Others? The Profession, (April). http://doi.org/10.1017/S1049096511000242

Heywood, J. S., Wei, X., \& Ye, G. (2011). Piece rates for professors. Economics Letters, 113(3). http://doi.org/10.1016/j.econlet.2011.08.005

Ju, M. (2010). The Impact of Institutional and Peer Support on Faculty Research Productivity: A Comparative Analysis of Research Vs. Non-Research Institutions. Seton Hall University.

Jusoff, K., \& Samah, S. A. A. (2009). Developing Professional Track towards Excellence in Academician 's Career Path. Asian Culture and History, 1(2), 75-81.

Kaufman, R. R. (2009). Productivity in Scholarship Among Education Programs. Physical Therapy, 89(3).

Marrelli, A. F., Tondora, J., \& Hoge, M. A. (2005). Strategies For Developing Competency Models. Administration and Policy in Mental Health, 32(3), 533-561. http://doi.org/10.1007/s10488005-3264-0

Miller, J. C., Coble, K. H., \& Lusk, J. L. (2013). Evaluating top faculty researchers and the incentives that motivate them. Scientometrics, 97(3). http://doi.org/10.1007/s11192-013-0987-7

Mouton, J., \& Waast, R. (2009). Comparative Study on National Research Systems: Findings and Lessons. In V. L. Meek, U. Teichler, \& M. Kearney (Eds.), Higher Education, Research, and Innovation: Changing Dynamics, Report on the UNESCO Forum on Higher Education, Research 
INTERNATIONAL JOURNAL OF ACADEMIC RESEARCH IN BUSINESS AND SOCIAL SCIENCES

Vol. 8, No. 10, Oct. 2018, E-ISSN: 222 2-6990 @ 2018 HRMARS

and Knowledge 2001-2009. International Centre for Higher Education Research Kassel (INCHERKassel), University of Kassel.

Nonaka, I., Byosiere, P., \& Borucki, C. C. (1994). Organizational Knowledge Creation Theory : A First Comprehensive Test, 3(4), 337-351.

Nonaka, I., \& Krogh, G. Von. (2009). Tacit Knowledge and Knowledge Conversion: Controversy and Advancement in Organizational Knowledge Creation Theory. Perspective Organization Science, 20(3), 635-652. Retrieved from https://doi.org/10.1287/orsc.1080.0412

Nonaka, I., Krogh, G. Von, \& Voelpel, S. (2006). Organization Studies Evolutionary Paths and Future Advances. http://doi.org/10.1177/0170840606066312

Nonaka, I., \& Takeuchi, H. (1995). The Knowledge-Creating Company: How Japanese Companies Create the Dynamics of Innovation. Oxford University Press.

Nonaka, I., \& Toyama, R. (2005). The theory of the knowledge-creating firm : subjectivity, objectivity, and synthesis, 14(3), 419-436. http://doi.org/10.1093/icc/dth058

Nonaka, I., Toyama, R., Hirata, T., \& Edwards, J. S. (2009). Managing flow : a process theory of the knowledge-based firm Reviewed by :, 113-115. http://doi.org/10.1057/kmrp.2008.39

Robbins, S. P., \& Judge, T. A. (2009). Organizational Behavior (13th ed.). New Jersey: Pearson Prentice Hall.

Saunders, M., Lewis, P., \& Thornhill, A. (2008). Research Methods for Business Students. Research methods for business students. http://doi.org/10.1007/s13398-014-0173-7.2

Siemsen, E., Roth, A. V, \& Balasubramanian, S. (2008). How motivation, opportunity and ability drive knowledge sharing: The constraining-factor model. Journal of Operations Management, 26, 426-445. http://doi.org/10.1016/j.jom.2007.09.001

Spencer.Jr., L. M., \& Spencer, S. M. (1993). Competence at Work. New York: Wile. http://doi.org/10.1002/hrdq.3920050411

Tian, J., Nakamori, Y., \& Wierzbicki, A. P. (2009). Knowledge management and knowledge creation in academia : a study based on surveys in a Japanese research university. Journal of Knowledge Management, 13(2), 76-92. http://doi.org/10.1108/13673270910942718

Travaille, M., \& Hendriks, P. H. J. (2010). What keeps science spiralling ? Unravelling the critical success factors of knowledge creation in university. Higher Education, 59, 423-439. http://doi.org/10.1007/s10734-009-9257-2

Tuuli, M. M. (2012). Competing Models of How Motivation, Opportunity, and Ability Drive Performance Behaviours. In W. Laryea, S., Agyepong, S.A., Leiringer, R. and Hughes (Ed.), Procs 4th West Africa Built Environment Research (WABER) Conference, 24-26 July 2012, Abuja, Nigeria (pp. 1359-1366).

Zainab, A. (1999). Personal, Academic and departmental correlates of research productivity: A review of the literature. Malaysian Journal of Library \& Information Science, 4(2), 73-110. 